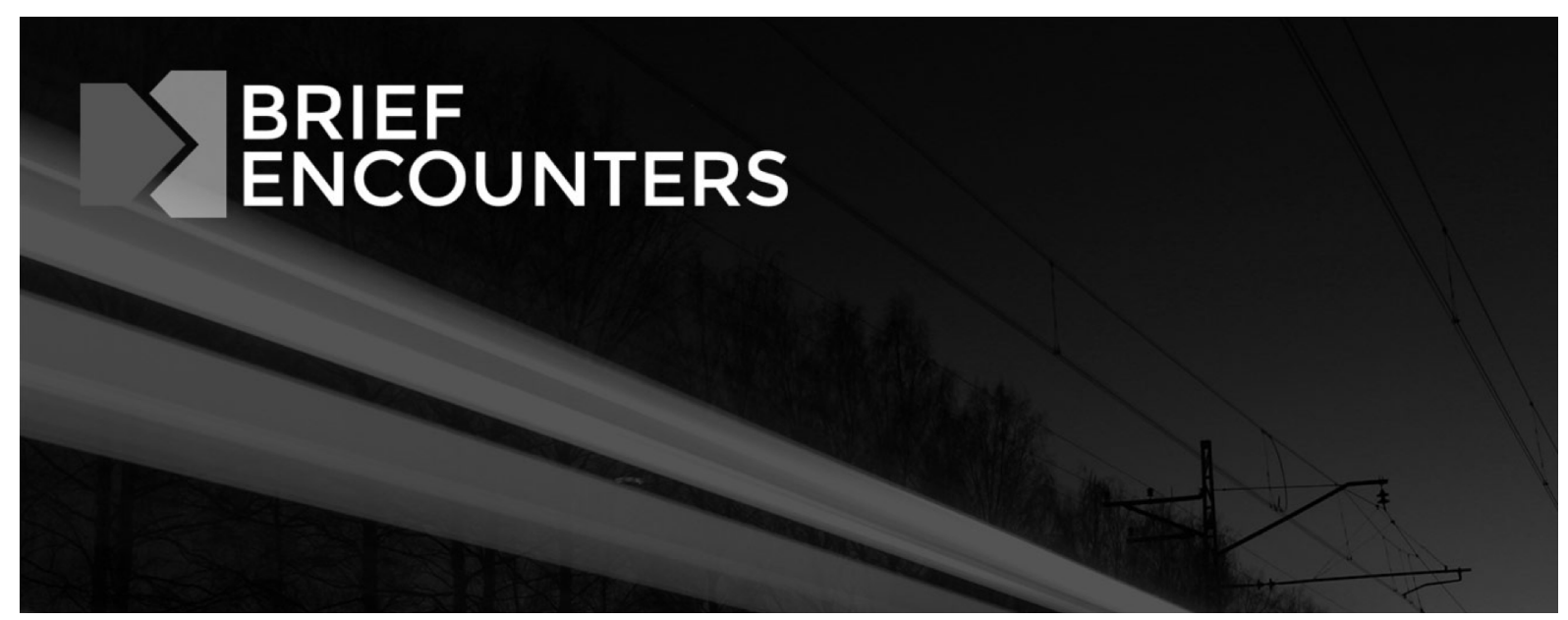

ISSN 2514-0612

Journal homepage: http://briefencounters-journal.co.uk/BE

Liminal Fiction: An Interdisciplinary Approach to Researching, Writing and Disseminating an Archival Novel about the Violent Past

Author(s): Penny Claire Simpson

Email: pcsimp@essex.ac.uk

Source: Brief Encounters Vol.1, No. 1 (Feb 2017)

URL: http://briefencounters-journal.co.uk/BE/article/view/24/

DOI: http://dx.doi.org/10.24134/be.v1i1.24

(C) Penny Claire Simpson, 2017

License (open-access): This is an open-access article distributed under the terms of the Creative Commons Attribution License 4.0, which permits unrestricted use, distribution, and reproduction in any medium, provided the original work is properly cited. No warranty, express or implied, is given. Nor is any representation made that the contents will be complete or accurate or up to date. The publisher shall not be liable for any actions, claims, proceedings, demand or costs or damages whatsoever or howsoever caused arising directly or indirectly in connection with or arising out of the use of this material.

Brief Encounters is an open access journal that supports the dissemination of knowledge to a global readership. All articles are free to read and accessible to all with no registration required. For more information please visit our journal homepage: http://briefencounters-journal.co.uk/BE. 


\title{
Liminal Fiction:
}

\section{An Interdisciplinary Approach to Researching, Writing and Disseminating an Archival Novel about the Violent Past}

\author{
Penny Claire Simpson
}

\section{Writing the Liminal}

In coining the term liminal fiction, I have drawn on the Latin root for the word 'liminal,' that is to say, 'limen,' or 'threshold,' as defined in the Oxford English Dictionary. Liminal fiction, like the field of transitional law, is always in the 'process of becoming,' revealed through discovery, chance and allusion, as much as by constructed ideas of a verifiable truth, or closed historical narrative. ${ }^{1}$ It allows for the embodiment of an affective truth, what Griselda Pollock calls memory in transit, but arguably is also a definition of a fictional space built on the liminal. Here, 'storytelling and document play games with the normal distinctions between fact and fiction, truth and lies.'2

In this article I demonstrate that a novel responding to developments in the field of transitional justice requires a liminal treatment, largely because it is a sector that is itself experimental, offering up a malleable and fluid setting in which new institutions and customs come into being as a state moves from conflict to peace. Accordingly, as part of my research methodology, I have been taking a unique approach to working in the archive. My intention is to construct a series of chronologically non-linear narratives for my novel using archival material, bringing my imagination into play and allowing unexpected discoveries and

\footnotetext{
${ }_{1}^{1}$ Martha Minow, Between Vengeance and Forgiveness: Facing History After Genocide and Mass Violence (Boston: Beacon Press, 1998), p. 33

2 Griselda Pollock, After-Affects/After Images: Trauma and Aesthetic Transformations in the Visual Feminist Museum (Manchester: Manchester University Press, 2013), pp. 266-67.
} 
seemingly random materials and artefacts to speak to each other across the intellectual and physical boundaries between diverse archival institutions.

In this way, an archive becomes a malleable space too, rather than one confined by rigid classification models, rich in potential for developing creative research methodologies in keeping with the experimental nature of the sphere of transitional justice. It provides a liminal experience for the researcher, offering as it does an effective device for creating innovative ways of representing transitional and diaspora communities in post-conflict, post-authoritarian worlds, a key theme of my fictional narrative. It will also investigate the process of recovering histories and the delivery of a form of cultural recovery through adopting a shape-shifting framework that owes much to the concept of the labyrinth, a point I will return to later.

The Spanish Collection housed at the Marx Memorial Library in London includes marketing materials produced by a number of charitable organisations fundraising for Spanish civilians displaced by the 1936-1939 civil war. I was particularly drawn to the plastic envelopes filled with coupons and tokens which were sold to raise milk for babies, and a donation card marked up with the different parts of a man's suit, enabling a contributor to save up over a period of time and provide clothing for a refugee going into exile. Researching earlier in the Whitechapel Art Gallery Archive, I came across letters and documents that echoed such initiatives and the motive behind them: the determination to fight the threat of fascism and to stop it spilling from Spain into Europe and beyond. I had been looking for references to the exhibition of Picasso's Guernica in 1939 at the gallery, but there was very little information inside the relevant box folder. What I did find was a large correspondence between the gallery and representatives of local immigrant communities who had used the space for a variety of artistic and social projects in the 1930s and 1940s. There were two short notices from contemporaneous news reports about Guernica, but they became intriguing footnotes to this rich collation of materials that brought to life people who had experienced and survived some of the major conflicts of mid-twentieth-century Europe. 
This unexpected treasure trove found inside archival box folders and plastic wallets has helped shape my idea of incorporating an imagined archive within my fiction. It has also prompted a key research question: what is process, and what is narrative when working on a liminal text? Arguably, creative research requires a symbiosis between the two, and I want to explore this further. Before looking more closely at this question, however, I will briefly discuss the background to my choice of subject matter - transitional justice in Spain - and my approach to setting up a research methodology, partly shaped by contemporary visual artists exploring the art of forensics, and the use of creative narrative devices by social and forensic anthropologists.

\section{'Cartography of Terror'}

Transitional justice has long been associated with its place of origin, the Latin American countries of the Southern Cone; however in 2016 it is Spain, a member state within the European Union, which is seen to support a culture of impunity. Attempts made to achieve reconciliation over the past have become mired in controversy and government inaction. Spain is, in essence, a pivotal site for exploring transitional justice issues within the mode of liminal fiction.

To date, no one has been convicted for the disappearances during the Spanish Civil War and the dictatorship that followed. Francisco Franco was the leader of the successful rebellion that overthrew the Spanish democratic republic and established the dictatorship that was to define the country until his death in 1975. Attempts to try human rights abusers in the Franco era have been blocked, or stalled, with devastating consequences for those seeking recognition for the estimated 114,226 victims of enforced disappearances. ${ }^{3}$ To put

\footnotetext{
3 'Report of the Working Group on Enforced or Involuntary Disappearances on the Mission to Spain 2013', <http://www.ohchr.org/ EN/HRBodies/HRC/RegularSessions/Session27/Documents/A-HRC-27-49-Add1_en.doc> [accessed 6 August 2016].
} 
this figure in context, a record of approximately 31,500 missing persons has been established in Bosnia following the 1992-1995 civil war. ${ }^{4}$

It is interesting to note that in the early 2000s, it was writers, artists and filmmakers, alongside Spanish civil society associations, who began the process of spearheading public debate around historic human rights violations. Many of these creative works explore the shifting nature of remembrance across the generations, opening up new ways of narrating the connectivity between embodied memory and human rights. Spanish civil society associations took up the challenge by helping the relatives of the disappeared locate, exhume and honour those killed in the civil war and the ensuing Franco dictatorship. Indeed, memorywork taking place around mass graves is making visible what social anthropologist Francisco Ferrándiz defines as a previously 'neglected cartography of terror and repression.' ${ }^{5}$

This aspect of memory-work has inspired contemporary Spanish artists such as Francesc Torres to bring his working practice out of the studio and to the graveside. Torres's historical documentation project, Dark is the Room Where We Sleep, consists of an exhibition and a photography book tracing the uncovering of human remains in a civil war grave in the province of Burgos in 2004. The publication takes on an innovative format: photographs of the exhumation team are juxtaposed with an array of other materials, including family photographs, testimony from villagers whose relatives are buried in the grave, and extracts from forensic identification reports. Francisco Ferrándiz contributes a text which departs quite radically from expectations of a standard academic text, as it is filled with striking visual imagery that captures the recovery of the 'memories of the defeated' in the manner of a prose poet. Describing Torres's photographic intervention, Ferrándiz states:

\footnotetext{
4 'Bosnia and Herzegovina', International Commission on Missing Persons (June 18 2014) <https://www.icmp.int/where-wework/europe/western-balkans/bosnia-and-herzegovina/> [accessed 2 August 2016].

${ }^{5}$ Francisco Ferrándiz, 'The Intimacy of Defeat: Exhumations in Contemporary Spain,' in Unearthing Franco's Legacy: Mass Graves and The Recovery of Historical Memory in Spain, ed. by Carlos Jerez-Ferrán and Samuel Amago (Notre Dame: University of Notre Dame Press, 2010), pp. 304-325 (p. 312).
} 
the bones prowl with his rage, his affection and his tenderness. They create a solemn transcript of assassinated dreams. Fugitive voices cling to the bullet hole, mutilated voices, skeletal voices [...] scattered voices, voices soaked with earth and blood [...] voices of a hidden rumour [...] suffocated voices, rehabilitated voices, living voices. Voices. ${ }^{6}$

In essence, by joining interdisciplinary exhumation teams, photographers and social anthropologists contribute to the development of a type of interactive graveside seminar that challenges the absence of state-led initiatives through direct collaboration with those affected by the original events who are encouraged to attend the proceedings. What they are doing in practice fits into theoretical frameworks by writers like Griselda Pollock who are formulating the concept of a new memory poetics. Drawing on Michael Rothberg's theory of a multidirectional memory, Pollock argues that artist and viewer must embark on a "'continual disturbance of the memory" in order to be able to create a new archive, a new body that incorporates the memory of the body missing.'7

Rothberg's writings on multidirectional memory stress the challenge of building such an archive within the wider context of how to address different histories of victimisation when they come into confrontation in the public sphere. One question I ask in my research is whether building this archive 'to the memory of the body missing' can be made possible through writing a liminal fiction, drawing on a creative research methodology which foregrounds the concept of a multidirectional memory and allows for the collapsing of borders between different archives, as well as competing historical accounts. As Rothberg states, works of fiction exploring the concept of a multidirectional memory open up 'a liminal zone between geographies and histories [...] allowing for ambivalent modes of belongings and exclusions.' ${ }^{8}$ The novel emerging from my research is poly-vocal, built around the theme of transmission of

\footnotetext{
${ }^{6}$ Franciso Ferrándiz, 'Fugitive Voices', in Dark is the Room Where We Sleep/Oscura es la Habitacion donde Dormimos, ed. by Francesc Torres (Barcelona: Actar-D, 2007), pp.12-28 p. 50.

7 Griselda Pollock, After-Affects/After Images: Trauma and Aesthetic Transformations in the Visual Feminist Museum (Manchester: Manchester University Press, 2013), p. 241.

8 Michael Rothberg, Multidirectional Memory: Remembering the Holocaust in the Age of Decolonization (Stanford: Stanford University Press, 2009), p. 3.
} 
narrative truths across generations and geographies. The concept of multidirectional memory is well suited to such an ambition; it also allows for an expanded notion of belonging and exclusion to be introduced into the writing process, a valuable means to incorporate the changing world of the exile, as well as representing the missing.

In order to respond to the challenge of creating a narrative of the missing, I want to utilise some of the methods used by these visual arts practitioners and forensic specialists to collapse complex, intertwined histories, both personal and collective, into patterns, and codes of symbols, which are then capable of being transferred into wider narratives of social justice. Theorising the relationship between archival detail and fabulation is a starting point; I will now identify some of the practical measures I will use, drawing on pioneering cases in transitional law, and transitional measures aimed at preventing non-recurrence of human rights violations.

\section{The Body's Testimony}

In 'The Intimacy of Defeat,' Francisco Ferrándiz states that the exhumation of mass graves is a form of memory-work that evolves over time, for 'each society has its own rhythms of absorption, overdose, and saturation of the traumatic past.' ${ }^{\prime}$ He analyses the 'clandestine resistance and survival strategies' of those repressed by the Nationalist victory, ranging from 'tiny domestic routines to protective silence, fugitive telling, decisions to join the resistance or proscribed political parties, and going into exile.'10 These strategies are rich in potential for the writer of fiction too, particularly when utilised to contribute to the emergence of a new paradigm in memory studies, as discussed earlier - one rooted in visual images of the exhumation of disinterred remains. Indeed, one of the narrative strands in my liminal fiction will be the honouring in secret of the site of a mass grave.

\footnotetext{
${ }^{9}$ Ferrándiz, 'Fugitive Voices', p. 310.

10 Ibid., p. 315.
} 
I will discuss later the idea of the labyrinth-grave as a structuring device, but for the time being I want to draw attention to this idea of a body's testimony being used as a means to open up possibilities of representation within a liminal fiction. It dovetails with the groundbreaking cases being brought before the Inter-American Court of Human Rights surrounding violations such as enforced disappearances, clandestine burial and extra-judicial killings. An example is the 1988 Velásquez-Rodríguez case which examined the systematic use of disappearances by the government of Honduras against its own citizens as a means of creating a general state of terror. ${ }^{11}$ It concerned the fate of a student who had been 'disappeared.' No body was found, so in order to determine what had happened to him after his abduction from a city street the narrative brought before the court had to be built up through establishing and corroborating the modus operandi adopted by security forces linked to the State in similar cases. To this end, the narrative trajectory was presented in such a way that the existence of clandestine prisons and the practice of clandestine burials was brought to the fore. In other words, the focus was put on the 'body's testimony' in a process of documentation that was given striking visual representation in the media where images of disinterred remains began to be published. Such imagery, as discussed earlier, has been central in the development of a new memory poetics.

The narrative brought before the court helped map the shadow presences and hidden burial sites of Honduras; in Spain, a landscape of post-memory is being mapped in image and word by photographers such as Francesc Torres, who reveals the existence of shadow 'archives,' or mass graves, in his historical documentation projects. I am developing my work of liminal fiction against such a background, using the body's testimony as a catalyst for evolving human rights norms across geographical and institutional boundaries, and for building traction for such concepts within the cultural memory. In addition, I aim to draw the

\footnotetext{
${ }^{11}$ Case of Velásquez-Rodríguez v. Honduras, Inter-American Court of Human Rights, Judgement of July 291988 (Merits) <http://www.corteidh.or.cr/docs/casos/articulos/seriec_04_ing.pdf> [accessed 3 August 2016].
} 
reader in as a co-curator of a narrative, which will consist of text, imagery, pieces of 'evidence,' as well as clusters of 'testimonial objects,' which must be sifted through like the artefacts and findings of a forensic investigation. My key literary motif is the labyrinth which will draw these different approaches together in a series of intertwining narratives, spanning three generations and three European countries.

\section{The Labyrinth-Archive}

In my novel, I present the idea of the mass grave as a form of labyrinth-archive. To that end, my research analyses the ways in which literal and metaphorical labyrinths have been used as an interpretative tool in classical and medieval literature. There are approaches and devices in this literature that I will adapt for my fictional purposes, primarily the idea of the labyrinth as a protean space, a motif for mass grave and archive, and the 'doubling' of the figures of Ariadne and Daedalus (architect of the Cretan labyrinth) in one of my principal characters. As Penelope Reed Doob states, the idea of the labyrinth possesses a 'tricky convertability,' as does the original legend of Ariadne and the Labyrinth. ${ }^{12}$ By medieval times, the text itself was regarded as a labyrinth and a scholar conforming to the 'the labyrinthe aesthetic' lay emphasis on the importance of both process and content working together, as well as the 'interpretative activity of audience/reader.' ${ }^{13}$ This approach reflects my idea of re-configuring the relationship between reader and writer, turning them into co-curators of a text, which, like Ariadne's thread, maps a network of allusions and patterns of histories.

The doubling motif is also important in this approach. Philosophers in medieval times were regarded as being both Ariadne and Daedalus, because of an ability in their labyrinth-

\footnotetext{
12 Penelope Reed Doob, The Idea of the Labyrinth from Classical Antiquity through the Middle Ages (London: Cornell University Press, 1992), p. 38.

13 Doob, p. 220.
} 
like manuscripts to combine these characters' methods of escape, namely through 'retracing and ascending.'14 Daedalus constructs wings for himself and his son Icarus to fly, whilst Ariadne presents Theseus with a 'clew of thread' to find his way out of the labyrinth after slaying the Minotaur.

In my liminal fiction, I expand on this metaphor of the labyrinth to encapsulate a postconflict environment where the geographical wanderings of those in exile map out a pictorial labyrinth of survival and transition. The character bringing this pictorial labyrinth into being is an artist, who is presented through the 'doubling motif' as both Ariadne and Daedalus - in other words, a guide/curator and a craftswoman/artist. Her chance discoveries in an archive in the East End of London inspire the narrative threads for an archival artwork based around the exhumation of a mass grave in Spain in 2011, a time of large-scale anti-austerity protests and demonstrations against the government by the 'Indignados' protestors, amongst others. The grave is situated on the outskirts of a small town where some eighty years previously a crime against humanity has been committed. Relatives of the victims in the grave appear in the artwork, the genesis of which forms part of the liminal narrative. The life of the artwork, the lives of the Spanish exiles and that of the artist intersect across different times, and on different planes of memory, in accordance with the precepts of Rothberg's notion of a multidirectional memory. I will now turn to a discussion of my approach to writing a visual text that embodies these narrative devices.

\section{'Denkbilder'}

In my creative fiction, the labyrinth-grave serves as both metaphor, and framework; the myriad secrets it opens up to the world disseminated through a prose built around Walter Benjamin's concept of Denkbilder, or 'reflections in imagery.' In his work Berlin Childhood around 1900 he creates a highly imaginative alternative to the writing of a traditional

\footnotetext{
14 Ibid., p. 265.
} 
autobiography. In a set of short pieces, unified through the device of Denkbilder, Benjamin analyses the act of remembering; to remember is to seize on a 'fugitive knowledge,' the kind that is glimpsed in deserted places, where past, present and future seem to collide:

For just as there are plants that are said to confer the power to see into the future, so there are places that possess such a virtue. For the most part, they are deserted places - treetops that lean against walls, blind alleys or front gardens where no one stops. In such places, it seem as if all that lies in store for us has become the past. ${ }^{15}$

I utilise this idea of memory as palimpsest in my novel which centres on the exhumation of a mass grave, a place where 'no one stops' because for decades its existence has been denied, even if secretly mourned by some. The grave suggests a place of permanent closure and silence, but in the novel I want to evoke the sense of the labyrinth-grave as possessing another dimension, a metaphorical one in which it serves to open up 'myriad passages' for a questing reader to follow. I consider the man-made grave as being like a shell, another labyrinth-like structure. In Gaston Bachelard's analysis of The Poetics of Space particular emphasis is laid on the relationship between word and shell, one I would like to use as a Denkbilder within my novel: 'Words are clamour-filled shells', Bachelard states, 'There's many a story in the miniature of a simple word.' ${ }^{16}$ I present the labyrinth-grave as a form of Denkbilder; it resembles Ariadne's 'clew of thread,' tightly bound, its intricate, labyrinth-like history made up of interweaving narratives, a 'fugitive knowledge' of contested histories, silenced voices, competing truths and forgotten identities.

\footnotetext{
15 Walter Benjamin, Berlin Childhood around 1900, trans. by Howard Eiland (New York: The Belknap Press of Harvard University Press, 2006), p. 79.

${ }^{16}$ Gaston Bachelard, The Poetics of Space, trans. by John R. Stilgoe (Massachusetts: Beacon Press, 1994), p. 179.
} 


\section{'Museum of Space and Emotion'}

In researching and writing a liminal fiction, I am also considering how such a work will be disseminated, particularly as it is taking on a hybrid form, consisting of part-book, part-archive, partinstallation. As discussed earlier, I see the labyrinth, the archive and the mass grave as malleable spaces, particularly when negotiated by a writer, artist or scientist working within the paradigm of multidirectional memory. Indeed, my work of liminal fiction is going to develop around an archival artwork, one that expands on the notion of archive. It is an approach I see reflected in the development of new museums of space and emotion, such as 19 Princelet Street in Spitalfields, London.

Just as reading Benjamin's unorthodox autobiography leads to new ways of thinking about history and memory, so does a visit to a site like 19 Princelet Street. It is not a museum in the conventional sense of the word, as its history and contemporary significance lie in its bricks and mortar. In the $18^{\text {th }}$ century, the building was home to a family of Huguenot silk weavers who fled persecution; in 1869, a synagogue was erected in the garden by Jewish emigrants from Eastern Europe. ${ }^{17}$ This is a space where Rothberg's concept of a multidirectional memory quite literally finds its embodiment; it is embedded in the gilt lettering on the wooden gallery in the synagogue spelling out the names of those who once prayed on its benches, and in the trail of paw prints left by an intrepid cat in the steps leading down to the basement.

It is a museum of the intangible, of the many missing voices of those who passed through its spaces over the centuries. Arguably, it is in these shape-shifting spaces where connections are made between the narratives of the missing. In my new genre of liminal fiction I will incorporate 'the memory of the body missing' through writing a novel which will also take on a hybrid, shape-shifting form - it will be an archive, book, and installation. The contribution my genre of liminal fiction will make to the emerging field of the arts and transitional justice will be underlined through the close relationship I intend to establish between novel writing and undertaking ground-breaking interdisciplinary research in an academic environment.

\footnotetext{
17 'The House', 19 Princelet Street <http://www.19princeletstreet.org.uk/about.html> [accessed 3 January 2017]
} 


\section{Bibliography}

Bachelard, Gaston, The Poetics of Space, trans. by John R. Stilgoe (Massachusetts: Beacon Press, 1994)

Benjamin, Walter, Berlin Childhood around 1900, trans. by Howard Eiland (New York: The Belknap Press of Harvard University Press, 2006)

'Bosnia and Herzegovina', International Commission on Missing Persons (June 18 2014) <https://www.icmp.int/where-we-work/europe/western-balkans/bosnia-andherzegovina/> [accessed 2 August 2016]

Doob, Penelope R., The Idea of the Labyrinth from Classical Antiquity through the Middle Ages (London: Cornell University Press, 1992)

Case of Velásquez-Rodríguez v. Honduras, Inter-American Court of Human Rights, Judgement of July 291988 (Merits) <http://www.corteidh.or.cr/docs/casos/articulos/ seriec_04_ing.pdf> [accessed 3 August 2016]

Ferrándiz, Francisco, 'The Intimacy of Defeat: Exhumations in Contemporary Spain,' in Unearthing Franco's Legacy: Mass Graves and The Recovery of Historical Memory in Spain, ed. by Carlos Jerez-Ferrán and Samuel Amago (Paris: University of Notre Dame Press, 2010), pp. 304-325

—_ 'Fugitive Voices,' in Dark is the Room Where We Sleep/Oscura es la Habitacion donde Dormimos, ed. Francesc Torres (Barcelona: Actar-D, 2007)

'The House', 19 Princelet Street <http://www.19princeletstreet.org.uk/about.html> [accessed 3 January 2017]

Minow, Martha, Between Vengeance and Forgiveness: Facing History After Genocide and Mass Violence (Boston: Beacon Press, 1998) 
Pollock, Griselda, After-Affects/After Images Trauma and Aesthetic Transformations in the Visual Feminist Museum (Manchester: Manchester University Press, 2013) 'Report of the Working Group on Enforced or Involuntary Disappearances on the Mission to Spain 2013', A-HRC-27-49-Add 1, <http://www.ohchr.org/EN/HRBodies/HRC/ RegularSessions/Session27/Documents/A-HRC-27-49-Add1_en.doc> [accessed 6 August 2016]

Rothberg, Michael, Multidirectional Memory Remembering the Holocaust in the Age of Decolonization (California: Stanford University Press, 2009) 


\section{Buried, a work-in-progress}

Extract from the story of Félix Conesa 


\section{FOR OUR FRIENDS FROM SPAIN:}

\section{ENGLISH LESSONS}

Upper Hall, Whitechapel Gallery. Monday and Thursday evenings from 6 - 8 p.m.

A charge of $3 d$ per person (members of Affiliated Organisations, $2 d$ ) is made this week to contribute to the One Million Penny Fund, also supported by the gallery's exhibition of Picasso's 'Guernica'. 


\section{CONVERSATION EXERCISE III:}

\section{Topical Events}

"Coming round, anti-clockwise to your right, Félix, a list of useful words I've pulled together for discussing Picasso's Guernica this evening. Take one and pass it on. We will be going downstairs shortly to view the exhibition and then, after tea and biscuits, we shall resume the class with our discussion." 
Señorita Alice's List of Useful Words:

page 1

artist, an/the

atrocity, an/the

attacked

bitter

black

blame, the

brave

damage,the

difficult

dramatic

fatal

fault; to be at

fear, a/the

fear; to

fight, to forget about, to

guilt, the

guilty, to be

heroism

illegal

immoral

impossible

invasion

invade

justify, to

know, to (facts)

liberation

liberty

lie, to

peace, a/the permit, to

political

population, a/the

proof, a/the

question, a/the

resist, to

unbearable

unjust

violence, a/the

visible

suffer, to

support, to

tell to,

tell a story, to

tell the truth, to

page 2

terrible

truth, a/the

truth, to tell the

why?

world, a/the

worse

the worst 


\section{'Weeping Silk'}

Mrs O'Leary makes him a present of her husband's work boots. A docker by trade and the boots barely broken in before he was sent to fight overseas. Stepping into dead men's shoes, but they are a good fit. Now, he hands them on, in turn, to whoever is left fighting for his benighted country. Picasso has asked visitors to Guernica to donate a pair of boots by way of entrance fee. 318 pairs have been donated to date. They line them up beneath the painting which covers a wall. The tally increases to 319 when he adds his boots, which are also $\mathrm{Mr}$ O'Leary's boots. He walks home barefoot.

His feet are raw with the January cold. Snow melts down gutters. He feels a moriña, a homesickness, which overwhelms him, much more than the freezing cold. He loses sensation in his toes, but his heart still beats hard, and in his heart he remembers Málaga; he remembers tertulias held with his friends in Café de Chinitas, the long afternoons of debates, storytelling, and dreaming. His eyes sting with the cold. He can't feel his ears. His jaws ache. Hombres libres. That was how they saw themselves. Blind from the start. The painting he's just seen was a kind of truth. The warrior, dying, or already dead, his gloved hand clasping a small flower. (Hope springs eternal, says señorita Alice.) He can't feel his legs; his hands are ice cold. (Guernica is like a piece of war reportage, says señorita Alice.) His legs give way. When he breathes, it hurts. The cold scorches his lungs, burns his heart. There are no flowers in the gutter.

According to señorita Alice, Picasso drew the leather glove in a sketch he made in May, 1937. The glove was worn by a man who died in the destruction of Guernica. It is believed to be the 
only surviving memento of the 1, 654 Guernicans killed and the 7,889 wounded. Picasso, who owns the glove, says: "This is a tortured object found on the battlefield of liberty."

What survives in his memory? He slumps in the gutter, struggling to right himself. His arms are logs of ice. He remembers the rope soles of a dying woman's espadrilles spooling out into a stream of blood; he remembers the smell of clean sheets making him cry; he remembers a dancing girl-woman in a borrowed jacket; he remembers an idea he has of stitching the names of the dead inside the collars of the shirts of the living. He remembers this is his secret. It is like the little flower hidden in the palm of Picasso's dying warrior, but he remembers.

Someone else remembers. Colliot, the silk weaver, remembers the man he found half-dead on his doorstep. He rubbed at his bare feet with handfuls of mushy snow and forced a drop of brandy between his lips. Blue as bluebells in the woods, he said to his neighbours who had assembled to view the street show. When the man came to, he was all at sea in the middle of the gutter. Mumbled about gloves, and flowers, and a pair of boots. "He's been robbed," said one onlooker. Another thought he was a down-and-out. "What a shame, but war will pull us all down to his level, make no mistake."

Colliot suggests he come up to his room and take a turn by the fire. "A bit of a warm, sir. And I can order out for a pie, or a dish of eels." The words all blurry, but he liked the sound of the 'sir.' Decent of him, in the circumstances.

He remembers tumbling up the stairs, like a toddler still working out the use of its legs. He remembers the fire, and the pie, and Colliot sat reeling in front of him, bang, slap in the middle of a web of silk filaments, drawn from dozens of separate cocoons. A clever device of his own invention. Colliot, the silk weaver, who knows a secret too. The secret of the 'weeping 
silk.' Listen, he holds up his hand, as if about to perform the holy rites. Listen. He takes a piece of silk from a basket and scrunches it between his hands. "Can you hear? It sounds like a child sobbing." But how to make this finest of silks, he will not divulge. He says it is a secret brought over to England by the Huguenots, over a hundred years ago, and it will die with him. "If I could, Monsieur Colliot, I would always make shirts with such a silk," he says. 


\section{Rumpelstiltskin}

He does not forget his encounter with Monsieur Colliot. The minute he can, he makes a trip back to his attic room. He finds him at work, hunched in a labyrinth of threads, the twists of silk filament shining in the sunlight that pours down through the glass cupola cut in to the roof. Rumpelstiltskin and his gold. He says he wants to make a deal, and Colliot twitches an eyebrow. He stumbles on. He says he wants to buy up his stock of 'weeping' silk in order to make some very special shirts. Colliot twitches both brows. Fine silk shirts, every stitch done by his hand. There's more: he'll sew a secret inside each one. Colliot comes to a pause. "What secret?" In his old country, he says, many lie dead in unmarked graves. So, he has a plan: he will stitch each of their names inside a silk shirt of his own design; each of the dead, worn close to the heart of the living. Colliot is silent when he finishes speaking. He rubs his head; studies the backs of his hands. Then he bursts out laughing. "It is genius, sir, a book of mourning worn by us all."

And that's how it starts. The Finkelsteins take a cut for acting as go-between, introducing him to potential customers. First, the barristers and the lawyers, then the entertainers, singers and actors, some more gentrified than the others. And rumour plays its part too. Very soon, it's anyone with a taste for something fine. A last hurrah before the war with Germany begins, maybe. Some buy on tick, some pull sheaves of notes out of crocodile skin wallets. No questions asked, no lies told. And the names? Rest assured, there is never any shortage. There are always new names to add to the roll-call, as Franco's stranglehold on Spain deepens. He understands what he is doing is an act of defiance; it is a labour of love. He likes the idea of his father and his brothers, and their neighbours and friends, walking down the 
same streets, hidden away in a false seam, or inside the lining of a detachable collar. They might travel further afield, go up West and take in a show or a late night supper in a cabaret club. He has a suspicion his brother Ignacio would prefer the jellied eels his landlady Mrs O'Leary buys on Wednesday evenings for a treat. "My late husband's favourite," she says, by way of explanation. He likes the idea of bringing children back to life, criss-crossing the city in noisy disarray, tucked inside his shirts, evacuees from the colony no less, brought to the camps in England to be re-distributed to family homes, except an epidemic of galloping consumption had caught up with them first.

"The Grim Reaper," says Mrs O'Leary, "is none too choosey." She puts aside a third of the rent monies she collects each week to buy tins of milk for babies in Spain. The call is out for 100,000 tins to be collected for the next Food Ship leaving the docks. But this is a war that will rage beyond Spain's shattered borders. Anxiety builds and regulations chop and change. The British Committee for Refugees from Spain are to lose their office to an A.R.P store. The War Office sends a requisition notice and señorita Alice must find new premises to pack her parcels of second-hand clothing. He is next to come under fire; his 'Friendly Enemy Alien' status is questioned. Someone has notified the Home Office he is a communist and so a danger to Britain's patriotic citizens. Mrs O'Leary says "stuff and nonsense" and adopts the demeanour of a campaigning military general whenever any official dares venture through her backdoor with unwelcome queries. The Finkelsteins tackle paperwork on his behalf and provide references attesting to his standing in the neighbourhood. By the time war officially breaks out, he has received a rubber stamp on a document which confirms he is still a 'Friendly Enemy Alien.' "This is the true miracle," his friend says Kornbluth says. "To keep a friendly countenance in such troubled times. I salute you, comrade." 


\title{
Food Supplies sent to Catalonia and to the Central Zone
}

\author{
November $1^{\text {st }} 1938$ - March 31 1939
}

275 cases corned beef

3200 boxes 'Tuck' and 'Champ' Bar

16 tons special Australian butter

$3 \frac{1}{2}$ tons chocolate dessert box

1095 tons sugar

400 tons coffee

12 tons bacon

100 cases eggs

20 cases Berox cubes

100 tons steam coal

25 tons rice

70 tons cocoa

1310 cases condensed milk

$1801 \frac{1}{2}$ tons, 40 cases dried milk
10 tons peanut oil

228 tons soap

33 tons peas $\&$ beans

$1 \frac{1}{2}$ tons wholemeal flour

478 tons bread flour

4200 tons potatos

100 tons edible oil

100 tons cod liver oil

750 tubes dried liver extract

150 bottles yeast tablets (1000 each)

850 Ilb calcium glutonate

80 tons, 693 bales dried cod fish

2000 boys suits (special offer)

2500 pairs crepe \& canvas sandals

[From: The Spanish Collection, Marx Memorial Library, London <Box C/15] 


\section{Girl Running}

November. The streets are turning hazardous, because of the blackout. An early casualty of war is council worker Henry Godfrey, squashed by a car whilst out painting kerbstones white near Marble Arch. The newspapers have been full of it. He fears losing his cargoes of precious silks the same way; one slip, and under the wheels of a passing motor he will go, not unlikely with the game of hopscotch he is forced to play as he travels along the patchwork quilts of pavement markers. He negotiates for Kornbluth to accompany him to collect his weekly tally of cloth.

"If you trust him, I trust him."

"With my life, Monsieur Colliot."

"Let us not tempt Fate, not in times like these."

And so, a routine is established. He carries the silk, whilst his friend lights the way ahead as best he can with a lantern with a dimmer, and the boxes containing their gas masks strapped across his shoulder with thick string. At Colliot's workshop, they stand side by side, he wrapping the 'weeping silk' in tissue paper, Kornbluth placing it in the laundry boxes loaned by the Finkelsteins. Félix handles the material as if it were made from fragile cobwebs, gently blowing out its creases, before pressing down the tissue covers with little pats from the heels of his palms. He looks on in wonder when Colliot demonstrates how he extracts cloth from his loom, a sleight of hand that turns a piece of fabric into a puff of white mist. He claps and the silk billows up into a small canopy over the head of its maker. At least, that is what he 
believes he sees. Kornbluth thinks he hears a tempest of weeping run through the hundreds of strings, criss-crossing the ceiling overhead; instinctively, he holds up his hands to catch the falling tears. Back on the street, he tips what Kornbluth calls his Lorca hat in the direction of the newsagent's corner shop, even though the shopkeeper is obscured by the dozens of advertising placards lined up over the window:

No Mean City

This book will shock you! This book is on sale to Adults Only. 2/6.

Genuine Neapolitan ICES. Bricks 3d.

Take Home a Family Brick.

Fruit Lollies $2 d$.

Bird Citizen Ball Point Pens 3/9.

Authorised Agent for Pens and Refills.

Will's STAR cigarettes.

STOP! Here for American Comics.

Biggest collection in East London.

We Only Sell the Best.

The placards are out of date. German bombers have arrived and it is a long time since anyone ate a brick of ice cream, or leafed through a comic book. "The very idea," says Mrs O'Leary. "Jokes won't fill stomachs." 
No Mean City

Is a place of marauding, hungry dogs, and shell-shocked housewives stumbling to rescue trinkets from homes bombed into matchsticks; a clutch of kids, who have avoided evacuation, out running between the ruins, all chapped knees and conjunctivitis, cauliflower ears and toobig shoes borrowed from older siblings, newspaper sticking out the heels, threadbare sweaters and trousers billowing in the breeze with a twist of wire holding up the flies.

No Mean City

Is where women who still have windows to lean out of, lean out and shout their business to their neighbours passing below.

"Bombed flat as a plate, not a word of a lie. Couldn't even rescue her teeth."

"Six gone, all little 'uns from the same family, down the Dogs, yesterday night that was."

"And they took her front door for her man's laying out. Hung the shirts to dry in the gap, but you know, they was his shirts and that don't seem right either, does it?"

No Mean City

Is where she runs still; bobbed hair flying off her face; freckly face and snaggly teeth but the joy of it, seeing her running so free, a smile on her lips, dressed in a boy's school blazer, and her mother's tea dress with its botched sewn hem, and bare legs, and what must be her brother's shoes. And the girl is running, snaggly teeth, rumpled dress, and picture wire for shoelaces. And the girl is running towards him, like it is the end of a Hollywood movie and he is the hero, and she is his lover, and she is running and he holds his breath in case he might blow her away into another world. She is not running, she is dancing. She swivels her hips and waves her arms to a beat of her own making. And for a split second, no more, no less, he thinks it is her. The girl finishes her dance and she is running once more, ducks past him with 
maybe an inch to spare. He watches her disappear round the corner and it is on the tip of his tongue to shout out her name. He only manages a whisper, but here she comes, close enough to pull into his arms. He rests his chin on top of her head, and his hands sweep down the curve of her ribs. "Alba." She doesn't reply, but he feels her lean in, slipping her hands inside his shirt. Alba, a nom de guerre; he never did learn her real name. Is that why he hesitates to sew her name inside one of the silk shirts? He doesn't know who he would be bringing back to life.

But here she is, look, here someone comes - a ghost woman, running on the heels of the snaggly-tooth girl in her brother's shoes; a ghost woman running on the heels of history. 